\title{
A idade de ouro da cinefilia: crítica, rituais e paixões na França pré-revolucionária
}

\section{The golden age of cinephilia: critique, rituals, and passions in pre-revolutionary France \\ Marco Dreer Buarque}

Cinefilia: invenção de um olhar, história de uma cultura, 1944-1968. Antoine de Baecque. São Paulo: Cosac Naify, 2010.

$\mathrm{O}$ reconhecimento do cinema enquanto arte que melhor representou o século XX é algo relativamente recente e que não se deu ao acaso. Ao contrário, foi uma construção elaborada em um período específico e por uma geração que se fez distinguir pela aproximação incontida que mantinha com os filmes, incorporando uma série de rituais: manter um lugar determinado na sala em uma fila de-

Marco Dreer Buarque é mestre em Bens Culturais e Projetos Sociais pelo CPDOC/FGV do Centro de Pesquisa e Documentação de História Contemporânea do Brasil (CPDOC) da Fundação Getulio Vargas (FGV)e analista de documentação e informação pela mesma instituição. Rio de Janeiro, Brasil (marcodb@fgv.br). Resenha recebida em 23 de agosto de 2011 e aprovada em 2 de setembro de 2011.

Est. Hist., Rio de Faneiro, vol. 24, $n^{o}$ 48, p. 433-436, julho-dezembro de 2011. 


\section{Marco Dreer Buarque}

marcada, cultuar filmes marginalizados, inventariar os filmes já assistidos etc. Se, por um lado, já havia na década de 1920 uma tentativa por parte da intelectualidade francesa de legitimar o cinema como arte, foi somente a partir do final da década de 1940 que uma geração ávida por filmes conseguiu elevar o cinema a uma posição antes impensável junto ao panorama das artes.

Autor de um vasto repertório de trabalhos voltados sobretudo para a historiografia do cinema francês, tendo sido responsável por biografias de Jean-Luc Godard e François Truffaut, Antoine de Baecque também fez carreira na redação da prestigiosa revista Cahiers du Cinéma. Cinefilia (2003) é o resultado de pesquisas que desenvolveu, acumuladas ao longo dos anos, reunindo nove ensaios, publicados inicialmente entre 1991 e 2000, além de três outros inéditos. O autor já havia explorado o tema nos dois volumes de Les Cahiers du Cinéma: histoire d'une revue (1991), e, mais recentemente, foi o responsável pelo roteiro de Godard, Truffaut e a Nouvelle Vague (2010), instigante documentário de Emmanuel Laurent que opera uma reflexão, a partir de um diverso uso de fontes, a respeito da crise instaurada no movimento em função do afastamento que se deu entre os dois personagens do título. Ainda que pertencente a uma geração posterior à retratada no livro, De Baecque assistiu de perto ao esvaziamento dos cinemas de rua, de modo que Cinefilia é não só uma radiografia de uma geração cinéfila, mas também uma narrativa sobre a relação desses espectadores com a própria prática pertinaz de frequentar as salas de cinema.

Mesmo que De Baecque mencione a primeira cinefilia ocorrida nos anos 1920, seu interesse recai inteiramente sobre o período que se estende entre as décadas de 1940 e 1960, no qual a cinefilia tomou formas passionais e obsessivas como jamais ocorrera na França ou alhures, de tal modo que, para os cinéfilos desses anos, $\mathrm{o}$ ato de ver filmes se misturava à própria vida. Ir ao cinema era um ato de amor desmedido, extensão da própria vida, motivador de debates infindáveis e de enfrentamentos marcados quase sempre pela pouca polidez entre as partes. Os filmes ganhavam uma dimensão e uma importância tamanhas que supostas regras de boa conduta eram solapadas em nome da defesa, quase bélica, dos autores e dos filmes mais apreciados.

Em Cinefilia, De Baecque sustenta que aquela geração operou uma reação ao cenário cultural que vicejava na França de então ao desconfiar de um tipo de cinema celebrado por sua suposta superioridade artística, e, ao mesmo tempo, apontar para as qualidades, sobretudo formais, encontráveis nos filmes norte-americanos, até então considerados entretenimento vulgar e descartável. Observou-se naquele momento, portanto, uma intensa reação contracultural que contestava tanto uma tendência antiamericana por parte de certa esquerda comunista quanto uma tradição da chamada "qualidade francesa", permitindo uma renovação do ambiente cultural francês bem como a eclosão do chamado cinema moderno, não só na França como também em diversos outros países. 
Na sua distribuição de capítulos, Cinefilia conjuga retratos de críticos franceses proeminentes do período (André Bazin, Georges Sadoul, François Truffaut, Roger Tailleur, Bernardo Dort e Serge Daney), episódios envolvendo a defesa de cineastas norte-americanos como exemplares de certa paixão cinéfila (Alfred Hitchcock e Samuel Fuller), além de dois episódios notáveis (a censura a A religiosa, de Jacques Rivette e o "caso Langlois”) que aproximaram a política da cinefilia, a qual, a partir de então, seria substancialmente transformada. Há ainda um saboroso e inusitado capítulo dedicado às musas das telas, mais particularmente à aproximação algo erótica que havia entre as estrelas (norte-americanas, em sua maioria) e os cinéfilos, merecendo destaque duas atrizes que acabaram por promover uma leitura renovada sobre a presença da mulher na tela (Harriet Anderson e Brigitte Bardot).

$\mathrm{O}$ autor recorre a três fontes principais, procurando cotejá-las a todo o momento: arquivos privados de personagens ligados à cinefilia na França; coleta de depoimentos, também de cinéfilos; e, finalmente, a análise de uma série de revistas fundamentais para a reflexão cinefílica. É importante mencionar que, dentro do amplo e heterogêneo universo de publicações abordado por De Baecque, são os Cahiers du Cinéma uma espécie de "centro nervoso" da crítica e da cinefilia francesas, cujos debates eram os mais contundentes e de onde sairiam os principais nomes que, ao final dos anos 1950, comporiam a chamada nouvelle vague.

Nesse painel de críticos montado por De Baecque, nota-se certo protagonismo de François Truffaut. Afora sua presença precoce e contínua nas revistas e jornais franceses que dedicavam espaço à crítica de filmes, Truffaut notabilizou-se sobretudo pelo estilo agressivo de sua pena, não poupando aqueles cineastas que não constassem no seu rol de "autores", os quais carregariam uma assinatura própria tal qual os grandes escritores. De Baecque esmiúça a "política dos autores" praticada principalmente nas páginas dos Cahiers du Cinéma pelos jovens críticos franceses, que, em função da veneração que demonstravam ter por cineastas como Alfred Hitchcock e Howard Hawks, passaram a receber, quase sempre em tom pejorativo, a alcunha de "hitchcock-hawksianos" pelos críticos das alas adversárias, alojados notadamente na revista Positif, mais à esquerda. Os "jovens turcos", como eram conhecidos, tinham Hitchcock e Hawks, entre muitos outros, como autores de cinema por excelência e promoviam uma verdade "estética": o elogio da mise en scène.

De Baecque joga nova luz sobre o célebre episódio envolvendo a tentativa de afastamento de Henri Langlois da direção da Cinemateca Francesa pelo governo gaullista, ocasião em que André Maulraux exercia a função de ministro da Cultura. O episódio - uma espécie de antecipação dos conflitos de maio de 1968, algo que pôde ser sentido nas ruas - envolveu a presença maciça de cinéfilos, cineastas e intelectuais franceses nas cercanias da Cinemateca Francesa, na 
tentativa de impedir a destituição de Langlois. A iniciativa foi um importante ponto de inflexão para uma geração que, de modo geral, desdenhava dos aspectos que escapavam minimamente do que era próprio à mise en scène, e que, dali em diante, não poderia mais viver fechada em uma sala escura, apartada do mundo. A partir do momento em que um personagem formador para toda uma geração, de certa forma o representante mais notável daquela paixão absoluta pelos filmes, estava na iminência de ser afastado pela política gaullista, os jovens cinéfilos e cineastas perceberam que toda uma cultura estava sendo ameaçada. Portanto, o episódio Langlois, três meses antes da eclosão de Maio de 68, torna o conflito necessariamente político.

Ainda que os aspectos formais da construção cinematográfica tenham perdido terreno para a urgência do cenário político, notável sobretudo a partir dos conflitos ocorridos na Cinemateca Francesa, é possível perceber que a questão da mise en scène jamais deixaria de ser determinante para o cinema francês dali em diante, e para todos os cinemas novos por extensão, desde a eclosão da jovem crítica em meados dos anos 1950. Filmar, no entanto, passou a ser um ato político, e não apenas uma experiência formalista.

Por outro lado, a cinefilia, na concepção de De Baecque, só retornaria com força muito mais recentemente, via consumo doméstico de DVDs e por meio do catálogo aparentemente infinito posto à disposição pela Internet. Ficaram para trás o ritual coletivo e a experiência da sala escura cuja tela é iluminada por um feixe de luz vindo de um projetor, elementos típicos de um período histórico no qual era depositada uma verdadeira crença no cinema - fenômeno que não se verificou antes e que não se repetiria depois. 